\title{
Productivity and Profitability of Jackfruit-Eggplant Agroforestry System in the Terrace Ecosystem of Bangladesh
}

\author{
Atiqur Rahman', Md. Abiar Rahman ${ }^{1 *}$, Md. Giashuddin Miah', Md. Azizul Hoque ${ }^{2}$, \\ Md. Mezanur Rahman ${ }^{1}$
}

${ }^{1}$ Department of Agroforestry and Environment, Bangabandhu Sheikh Mujibur Rahman Agricultural University, Gazipur, Bangladesh ${ }^{2}$ Department of Horticulture, Bangabandhu Sheikh Mujibur Rahman Agricultural University, Gazipur, Bangladesh

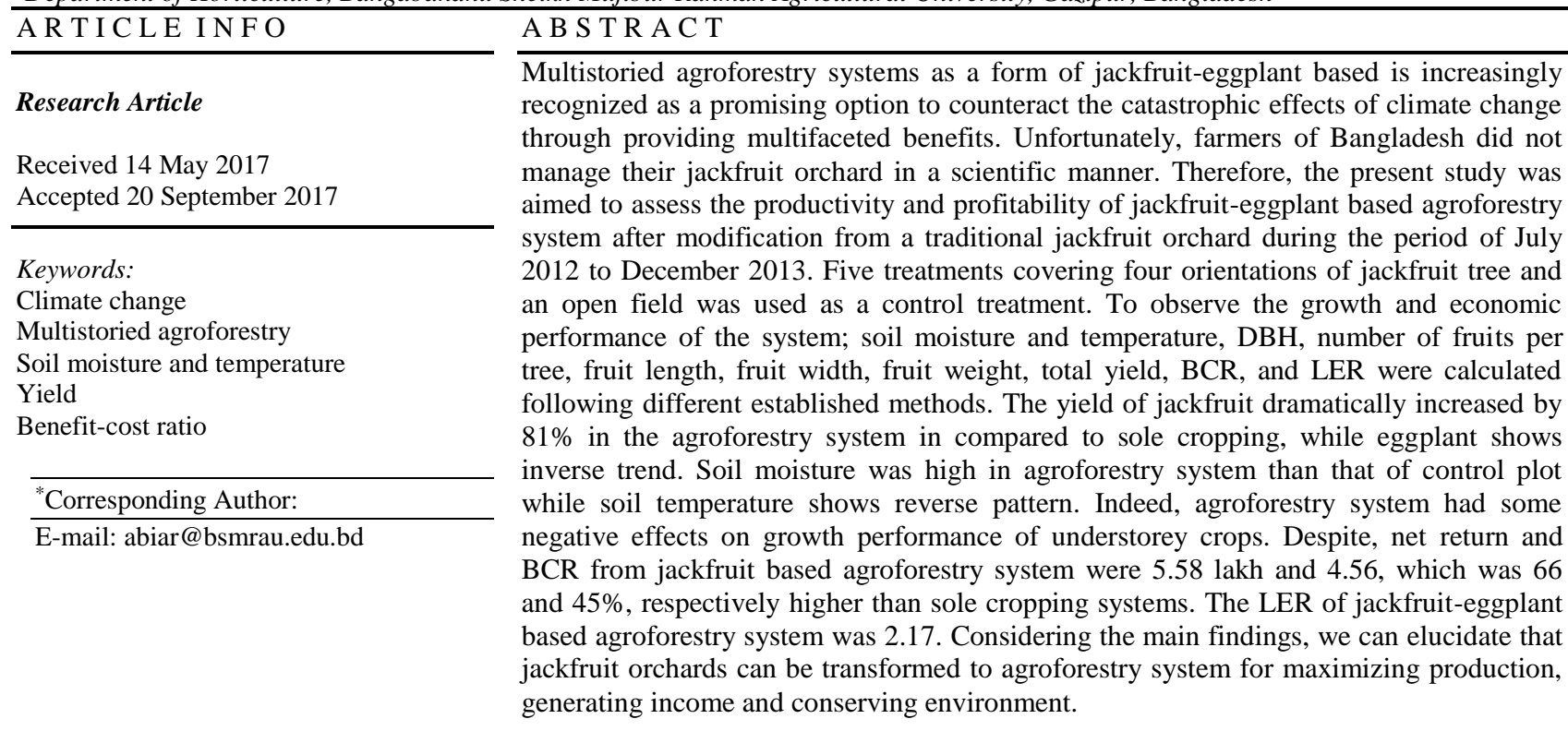

DOI: https://doi.org/10.24925/turjaf.v6i2.124-129.1330

\section{Introduction}

Bangladesh is situated at the interface of the two contrasting settings in the Bay of Bengal to the south and the Himalayas to the north with a very high population density of about 998 persons per $\mathrm{km}^{2}$ area (Abdullah and Rahman, 2015; Rahman et al., 2016). The livelihoods of millions of people hinge on agriculture, which acts as a mainstay of the economy. Agriculture is closely linked to food and nutrient security, and a broad-based source of income (Rahman et al., 2017). Under the current scenario of increasing human population and climate uncertainty, agricultural productivity would decrease along with the shrinking of cultivated land. Fascinatingly, the country has achieved impressive gains in food grain production in the last two decades and reached to near self-sufficiency at the national level by producing about 28 million metric tons of cereals, especially rice and wheat (BBS, 2011; Islam et al., 2016) along with dipping the population living under the poverty line from $57 \%$ in 1991 to $29 \%$ in 2012 (General Economics Division, 2013). Regardless of important gains in reducing poverty and increasing agricultural productivity, roughly $25 \%$ of the population is considered food insecure (Rich et al., 2015). In Bangladesh, although tremendous achievements have been made in agriculture sector due to technological development, non-technological factors such as high temperature, uneven rainfall are making agricultural production risky. On the contrary, even grain production increased significantly; there is a huge gap between demand and production of vegetables and fruits (Hasan et al., 2016). Therefore, it is needed to identify alternate production system that increases production in a sustainable manner by combining fruits and vegetables.

Agroforestry is increasingly recognized as a sustainable land use that enhances farmers' ability to adapt to climate change because of the multiple benefits including diversified products, supplementary income and environmental services (Lasco et al., 2011; Schoeneberger et al., 2012). It facilitates not only to upscale 
socioeconomic status of the farmers but also to enhance soil fertility, reduces erosion, improves water quality, conserves biodiversity, increases aesthetics and sequesters carbon to alleviate global warming (Nair et al., 2009; Hasan et al., 2016). Agroforestry is being practiced in Bangladesh since ancient time throughout the country with various patterns across the ecosystems because of disparities in topography, soil, water and climatic advantages (Miah et al., 2002).

Terrace ecosystem is a region of complex relief and soils developed over the Madhupur clay, comprising about $8 \%$ of the total land area of Bangladesh considered as one of the potential hotspots for performing agroforestry. Among divergence agroforestry systems that prevail in terrace ecosystems, jackfruit based system is dominant. Moreover, jackfruit is one of the most popular, delicious and important fruit trees in Bangladesh, which is widely found throughout the country. It is a perfect multipurpose tree as each and every parts of the tree can be utilized for instance seeds are used as vegetable, rind is used as supplementary feed for livestock and timber offers excellent carpentry and furniture making.

Jackfruit based agroforestry, however, is not practiced scientifically in the terrace ecosystem, therefore, farmers are not getting desired benefits. To maximize the production, economic benefits and environmental advantages from jackfruit based agroforestry practice, it is needed to develop a viable production model that ensures resource use, increases yields as well as economic and environmental benefits, as there is limited information of the jackfruit based agroforestry in the terrace ecosystem of Bangladesh. Considering the above facts and to explore a suitable fruit tree-vegetable combination, an on-farm research was designed to appraise the performance of upper-story jackfruit and lower-story eggplant plant.
Furthermore, microclimatic modification and economic return from the newly developed jackfruit based agroforestry was also evaluated to compare the profitability of traditional system.

\section{Materials and methods}

\section{Study location}

An On-Farm study was conducted during the period from July 2012 to December 2012 at Shibpur Upazila under Narsingdi district $\left(23^{\circ} 29^{\prime}\right.$ North latitude and $90^{\circ} 10^{\prime}$ East longitude), which is an ideal location of central terrace ecosystem of Bangladesh (Fig. 1). The climate of the area is mild both in the summer and the winter. The maximum and the minimum mean temperatures during winter vary from $19^{\circ}$ to $23.7^{\circ} \mathrm{C}$ and in summer from $26^{\circ}$ to $29^{\circ} \mathrm{C}$. The rainfall is generally heavy during the monsoon (July and August) and the mean annual relative humidity is about $74 \%$.

\section{Experimental design and treatment}

An established jackfruit orchard was transformed to agroforestry for the experimentation. Almost similar ages of jackfruit trees (10-13 years) were selected for imposing treatments. Nonetheless, jackfruit trees were kept as upper-story crop and widely cultivated Singnath eggplant variety was grown as lower-story crop. The experiment was conducted in a Randomized Complete Block Design (RCBD) with three replications. Each jackfruit tree was considered as a unit plot for a single replication. There were five treatments: open (non-agroforestry traditional farming), AF-S (agroforestry - south orientation), AF-N (agroforestry - north orientation), AF-E (agroforestry east orientation) and AF-W (agroforestry - west orientation).

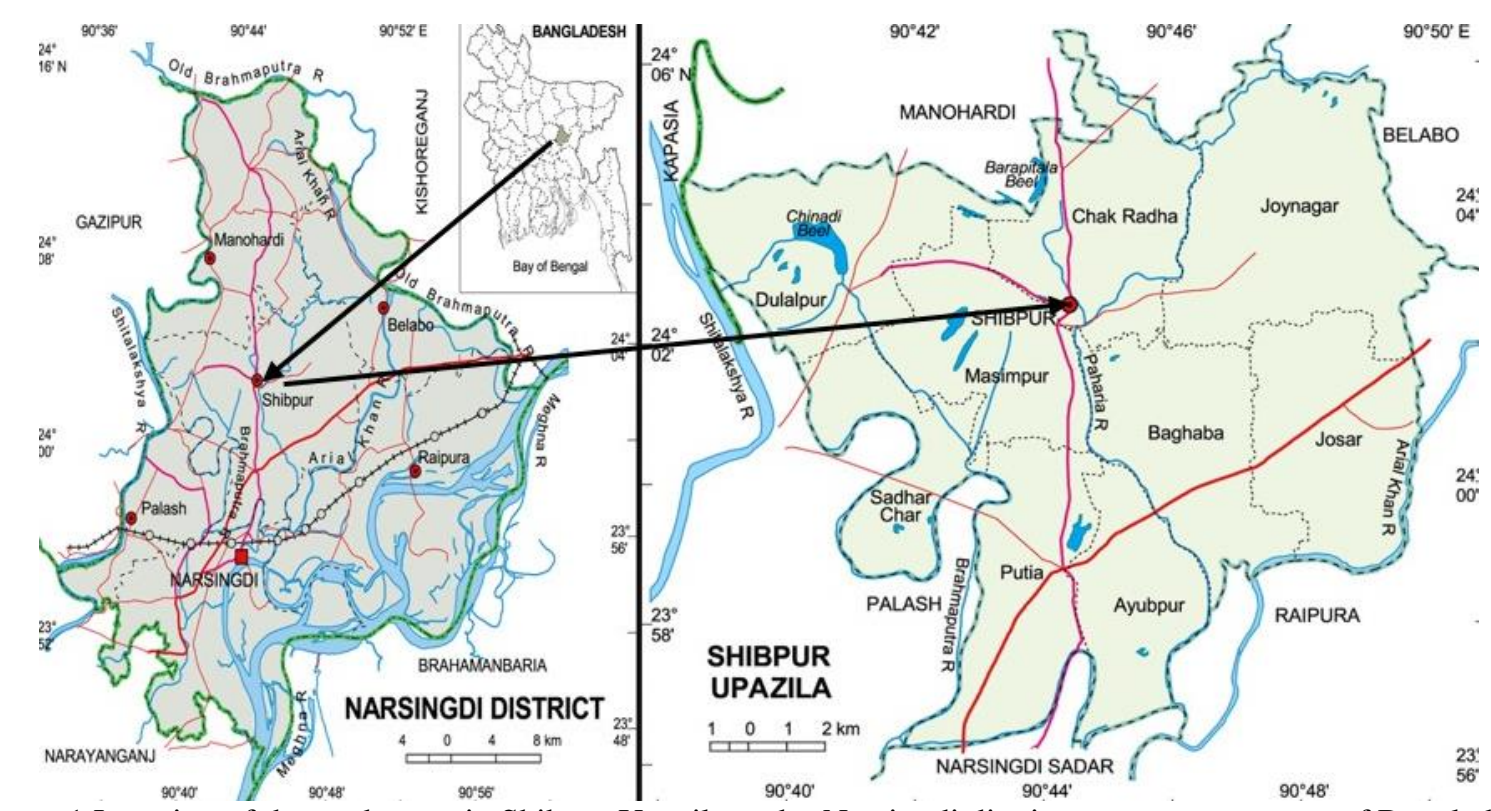

Figure 1 Location of the study area in Shibpur Upazila under Narsingdi district, terrace ecosystem of Bangladesh. 


\section{Field preparation and management practices}

For eggplant, land was prepared well by disking followed by harrowing and laddering until a good tilth was obtained. Land was fertilized by $\mathrm{N}, \mathrm{P}, \mathrm{K}, \mathrm{B}$ and cowdung at the rate of $115,75,78,11$ and $5000 \mathrm{~kg} \mathrm{ha}^{-1}$, correspondingly. Intercultural operations were done as and when necessary till end of the experiment. For controlling pest and diseases, Malathion $57 \mathrm{EC}$ and Dithene M 45 were used at the rate of $2 \mathrm{ml} \mathrm{lit}^{-1}$ and $2 \mathrm{~g} \mathrm{lit}^{-1}$, respectively. Poison bite and sex pheromone were also used to reduce the infestation of insects. No additional input was applied for jackfruit trees.

\section{Data collection and analysis}

To know the growth and yield performance of jackfruit, diameter at breast height $(\mathrm{DBH})$, fruit length, fruit width and fruit weight were measured as sole and agroforestry jackfruit trees. Five representative plants of eggplant were selected from each orientation for data collection. Samples were collected at 50, 70, 90, 110, 130 and 150 DAT. Fruit length, diameter and weight were measured at each harvesting and finally yield was calculated by summing up the weight of all fruits during the experimental period. Soil temperature and moisture were calculated periodically at every month interval to know the soil environment modification in agroforestry practice.

Benefit-cost ratio (BCR) is the ratio of gross return with total cost of production. It was calculated by using the following formula (Islam et al., 2004):

$$
\text { Benefit-cost ratio }(\mathrm{BCR})=\frac{\text { Gross return }}{\text { Total cost of production }}
$$

Land equivalent ratio (LER) is derived from its indication of relative land requirements for intercrops versus monocultures. It helps to find the relative performance of a component of a crop combination compared to sole stands of that species (Mead and Willey, 1980). The LER was measured as:

$$
\text { Land equivalent ration }=\frac{\mathrm{Ci}}{\mathrm{Cs}}+\frac{\mathrm{Ti}}{\mathrm{Ts}}
$$

Where, $\mathrm{Ci}$ is crop yield under agroforestry, Cs is crop yield under sole cropping, $\mathrm{Ti}$ is tree yield under agroforestry, and Ts is tree yield under sole cropping.

The data were statistically analysed using the "Analysis of Variance" (ANOVA) technique with the help of computer package "Statistix 10" to examine the significant variation of the results due to different treatments. The mean differences were adjusted by least significant different (LSD) at the 5\% level of significance.

\section{Results}

\section{Performance of Jackfruit}

Performance of jackfruit tree was measured before (sole) and after (agroforestry) the experimentation. A comparison of the performance of jackfruit between sole
(2012) and agroforestry (2013) practices has been demonstrated in Table 1 . The diameter at breast height (DBH) of jackfruit tree as sole crop was $20.95 \mathrm{~cm}$ that rose to $21.87 \mathrm{~cm}$ as agroforestry crop. Fascinatingly, the individual fruit weight and fruit size were diminished in agroforestry practice than that of sole cropping and the rate of decrease for individual fruit weight, fruit length and fruit width was 12.13, 11.03 and $15.63 \%$, respectively. Surprisingly, the number of fruits per tree was increased significantly in agroforestry (72) than sole practice (35) and the rate of increment was $105.71 \%$. As a result, the total yield of fruit was increased by $80.75 \%$.

\section{Performance of Eggplant}

Performance of eggplant by evaluating various parameters has been presented in Table 2. Fruit diameter of eggplant did not vary significantly at different orientations of agroforestry and open condition. However, the highest $(28.67 \mathrm{~mm})$ and the lowest $(24.31 \mathrm{~mm})$ fruit diameters were recorded in control and at north orientation, respectively. Fruit length of eggplant was remarkably varied in open field and agroforestry practices. The longest fruit $(21.28 \mathrm{~cm})$ was noted in open condition, which was statistically similar to south orientation $(19.88 \mathrm{~cm})$ in agroforestry practice. Fruit length, however, grown at north, east and west orientations did not vary significantly. The maximum number of fruits (9.50) per plant was noted in open field, which was statistically similar to south orientation (8.33). Number of fruits per plant grown at different orientations in agroforestry practice did not vary significantly. Among the orientations, the maximum (8.34) and minimum (6.67) number of fruits per plant were recorded at south and north orientations, respectively. A significant variation was found in producing fruit weight of eggplant grown in open field and agroforestry practice. The highest weight per fruit $(91.33 \mathrm{~g})$ was noted at south orientation in agroforestry practice, which was statistically similar to open field $(90.00 \mathrm{~g})$. Fruit weight grown at other orientations (north, east and west) in agroforestry practice did not vary significantly, although the lowest value $(72.33 \mathrm{~g})$ was noted at north orientation. The maximum yield $(855.0 \mathrm{~g})$ per plant was noted in control treatment, which was statistically similar to south orientation (761.2 g) in agroforestry. Among the orientations, the maximum (761.2 g) and minimum (482.1 g) yield per plant were recorded at south and north orientations, respectively.

\section{Soil Moisture Content}

Initially, the soil moisture did not vary between agroforestry and open fields, but it was higher in agroforestry practice than open field at the following measurement dates (Fig. 2). During the first measurement date, soil moisture was slightly higher in open field than agroforestry plots. In July, moisture level did not vary significantly, although open field contained the highest moisture level $(9.12 \%)$ and north orientation contained the lowest moisture level $(8.58 \%)$. In August, open field retained the utmost moisture level (12.70\%) and north orientation contained the least level (10.87\%). In 
September, north orientation contained the paramount moisture level $(12.18 \%)$ and open field contained the minimum level (11.84\%). In October, the highest $(11.80 \%)$ and the lowest $(10.14 \%)$ moisture levels were recorded at east orientation and open field, respectively. In November, south orientation and open field retained the maximum $(12.45 \%)$ and the minimum levels $(9.83 \%)$ of soil moisture, respectively. At the final measurement date (December), west orientation contained the highest moisture level $(12.07 \%)$ and open field contained lowest level $(10.37 \%)$. Among the agroforestry plots, although the variation was minimum, but on an average the higher soil moisture was recoded at south orientation followed by west, east and north orientations.

\section{Soil Temperature}

In general, soil temperature was higher in open plot as compared to agroforestry plots (Fig. 3). Among different orientations, the soil temperature was not consistent. At the first measurement (July) date, the highest $\left(32.35^{\circ} \mathrm{C}\right)$ and the lowest $\left(30.47^{\circ} \mathrm{C}\right)$ soil temperatures were recorded at open field and east orientation, respectively. In August, east orientation contained the highest temperature $\left(30.99^{\circ} \mathrm{C}\right)$ and west orientation contained the lowest $\left(30.14^{\circ} \mathrm{C}\right)$ soil temperature. In September, north and east orientations contained the highest $\left(31.04^{\circ} \mathrm{C}\right)$ and the lowest level $\left(30.72^{\circ} \mathrm{C}\right)$ of soil temperatures, respectively. From October through final measurement dates, the highest soil temperature was found in open field and the lowest at north orientation in most of the cases.

Table 1 Performance of jackfruit tree as agroforestry and sole crops.

\begin{tabular}{|c|c|c|c|}
\hline \multirow{2}{*}{ Parameter } & \multicolumn{2}{|c|}{ Year } & \multirow{2}{*}{$\%$ Change } \\
\hline & Sole (2012) & Agroforestry (2013) & \\
\hline DBH $(\mathrm{cm})$ & $20.9( \pm 4.96)$ & $21.8 \pm(5.19)$ & 4.39 \\
\hline No. of fruits per tree & $35.0( \pm 2.32)$ & $72.0( \pm 2.87)$ & 105.71 \\
\hline Fruit length $(\mathrm{cm})$ & $39.0( \pm 3.11)$ & $34.7( \pm 2.51)$ & -11.03 \\
\hline Fruit width $(\mathrm{cm})$ & $75.5( \pm 5.26)$ & $63.7( \pm 4.39)$ & -15.63 \\
\hline Fruit weight (kg) & $23.9( \pm 1.39)$ & $21.0( \pm 4.62)$ & -12.13 \\
\hline Total yield $\left(\mathrm{kg}\right.$ tree $\left.{ }^{-1}\right)$ & $836.5( \pm 17.11)$ & $1512.0( \pm 16.76)$ & 80.75 \\
\hline
\end{tabular}

Figures in parenthesis indicate the standard error $( \pm \mathrm{SE})$ value.

Table 2 Performance of eggplant as agroforestry and sole crops.

\begin{tabular}{l|ccccc}
\hline \multicolumn{1}{c|}{ Treatments } & $\begin{array}{c}\text { Fruit diameter } \\
(\mathrm{mm})\end{array}$ & $\begin{array}{c}\text { Fruit length } \\
(\mathrm{cm})\end{array}$ & $\begin{array}{c}\text { Individual fruit } \\
\text { weight }(\mathrm{g})\end{array}$ & $\begin{array}{c}\text { Number of fruits } \\
\text { per plant }\end{array}$ & $\begin{array}{c}\text { Fruit yield } \\
\left(\mathrm{kg} \mathrm{plant}-\mathrm{k}^{-1}\right)\end{array}$ \\
\hline Open & $28.76^{\mathrm{a}}$ & $21.28^{\mathrm{a}}$ & $90.00^{\mathrm{a}}$ & $9.50^{\mathrm{a}}$ & $855.0^{\mathrm{a}}$ \\
AF-N & $24.31^{\mathrm{a}}$ & $15.30^{\mathrm{b}}$ & $72.33^{\mathrm{b}}$ & $6.66^{\mathrm{b}}$ & $482.1^{\mathrm{c}}$ \\
AF-S & $28.16^{\mathrm{a}}$ & $19.88^{\mathrm{a}}$ & $91.33^{\mathrm{a}}$ & $8.33^{\mathrm{ab}}$ & $761.2^{\mathrm{ab}}$ \\
AF-E & $24.67^{\mathrm{a}}$ & $17.72^{\mathrm{b}}$ & $79.17^{\mathrm{b}}$ & $7.17^{\mathrm{b}}$ & $567.6^{\mathrm{b}}$ \\
AF-W & $26.56^{\mathrm{a}}$ & $17.92^{\mathrm{b}}$ & $77.00^{\mathrm{b}}$ & $7.00^{\mathrm{b}}$ & $539.0^{\mathrm{b}}$ \\
\hline
\end{tabular}

Means followed by different letters differ significantly based on $\mathrm{LSD}_{0.05}$.

Table 3 Total cost and return from eggplant-jackfruit based agroforestry practice as compared to sole cropping.

\begin{tabular}{|c|c|c|c|c|c|c|c|}
\hline System & Crop & Cost & Income & Total return (BDT) & Net return (BDT) & $\mathrm{BCR}$ & LER \\
\hline Agroforestry & $\begin{array}{l}\text { Eggplant } \\
\text { Jackfruit }\end{array}$ & $\begin{array}{c}156695 \\
-\end{array}$ & $\begin{array}{l}456370 \\
258188\end{array}$ & 714558 & 557863 & 4.56 & 2.17 \\
\hline Sole & Eggplant & 156695 & 491860 & 491860 & 335165 & 3.13 & \\
\hline
\end{tabular}

USD $1=78$ BDT.

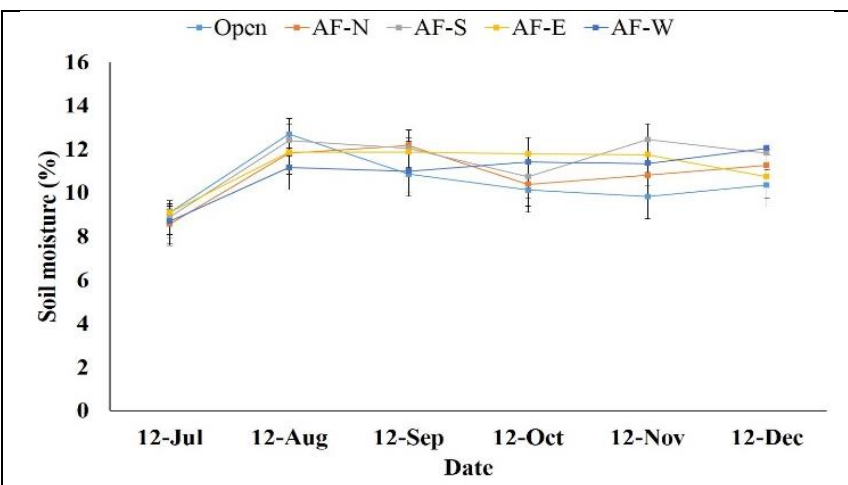

Figure 2 Soil moisture content over time at different orientations in agroforestry systems and open plot.

The measurement was done monthly basis and the first measurement was done at 50 DAT of eggplant seedlings. Vertical bars indicate \pm SE.

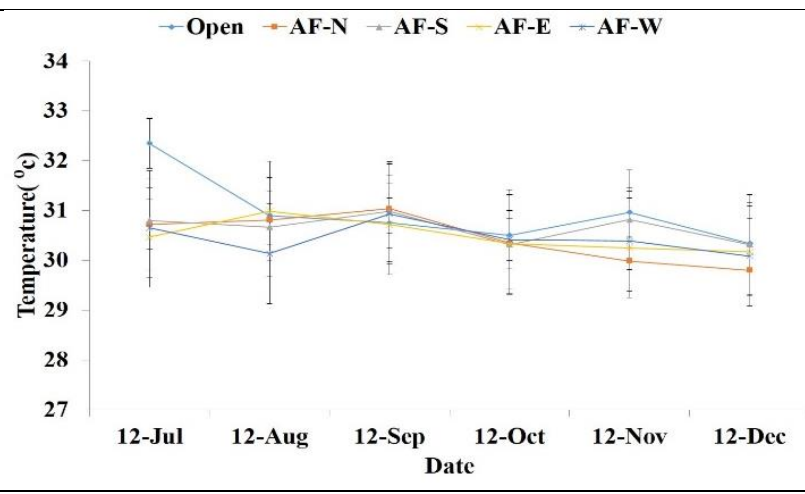

Figure 3 Soil temperature content over time at different orientations in agroforestry system and open plot.

The measurement was done monthly basis and the first measurement was done at 50 DAT of eggplant seedlings. Vertical bars indicate \pm SE. 


\section{Benefit Cost Ration (BCR) and Land Equivalent Ration (LER)}

To know the economic performance and land use in eggplant-jackfruit agroforestry system over sole cropping, benefit cost ratio (BCR) and land equivalent ratio (LER) have been calculated and presented in Table 3. The total cost for eggplant-jackfruit agroforestry system was BDT 275244, while the incomes from eggplant and jackfruit were BDT 456370 and BDT 258188 per hectare, respectively. On the other hand, the cost and income in sole eggplant system were BDT 156695 and BDT 491860 , respectively. The total return in agroforestry and sole cropping were BDT 714558 and BDT 491860; whereas the net returns were BDT 557863 and BDT 335165, respectively. The BCR for eggplant-jackfruit agroforestry system and sole eggplant was 4.56 and 2.17, respectively. The land equivalent ration for eggplantjackfruit agroforestry system was 2.17 , which is quite high. It indicates that 3.29 times higher land would be required to get similar production from sole cropping as compared to agroforestry system.

\section{Discussion}

The yield improvement of jackfruit in agroforestry system may be explained by good management of the system. In general, farmers do not manage their jackfruit orchard through the application of irrigation, fertilizer and pest management. However, in agroforestry system, sufficient irrigation, fertilizer and pesticides were applied for understory (eggplant) crops that were also enjoyed by jackfruit trees. Moreover, the fruit size was decreased in agroforestry practice may be due to huge bearing than sole system. The result what we found is corroborated by Uddin et al. (2010) in a Litchi-Indian spinach based agroforestry system.

The increase in fruit size for many fruit species is regulated by cell division, cell growth or a synchronized series of cell division and expansion (Yamaguchi et al., 2004; Zhang et al., 2006). However, the lower fruit diameter in agroforestry practice may be due to relatively higher shade with lower mobilization of reserve assimilates to reproductive organs. Similar observations were also reported by Rahman et al. (2010) on tomato cultivar in multistory agroforestry system. Fruits grown in open field received maximum light and more nutrients, which increased fruit length compared to that grown under tree species. Furthermore, shade created by evergreen jackfruit tree retard phloem imports, which also may be responsible for diminishing fruit length, hence to maximize fruit growth, appropriate sunlight exposure is essential (Morandi et al., 2011). Lower number of fruits per plant under relatively more and prolonged shaded conditions was probably due to poor photosynthetic capacity of plants, which encumbers reproductive growth of plants. The decreasing photosynthetic capacity of shaded plants was attributed due to both stomata and mesophyll cell properties (Hanif et al., 2010). Light availability was higher in open field compared to agroforestry system, which effect on fruit weight. The outcomes of our study are corroborated by Miah et al. (2008) on tomato cultivars under ghoraneem (Azadirachta indica) and sissoo (Dalbergia sissoo) based agroforestry systems. Diffuse light under agroforestry systems promotes the development of vegetative structures, while intense light favors the development of flowers, fruits and seeds (Weaver and Clements, 1973). In contrast, leaf litter inputs from agroforestry trees could provide sufficient nutrients and organic matter to sustain crop growth that may improve eggplant yield. Similar results were observed by Lehmann et al. (2002); Bhardwaj et al. (2005); Sarvade et al. (2014).

In sole cropping, the soil moisture content was slightly lower as compared to agroforestry practice, this may be due to the high rate of evaporation of water from the surface of open fields, particularly during the summer season. The noticeable difference in the soil moisture content on different aspects (south and west) and seasons showed that the southern aspect always possessed higher moisture content due to lower insulation which in turn gives birth to rich vegetation. However, during July, insolation period also increased the atmospheric and soil temperatures, which influenced soil temperature adversely and equilibrium is attained only after the monsoon showers are received in the months of August to September. The findings of our study are supported by Donohue et al. (1987).

The effect of trees on soil temperature is an important parameter for agroforestry systems, since the photosynthesis-respiration relationship depends largely on ambient temperature, plays a vital role in the accumulation of carbohydrate and in the control of the survival of crops in those systems. Lower temperature beneath tree crowns may reduce water stress and increase biomass of bellow crown species, if competition for light does not overcome the benefit of reduced temperature to the species beneath the tree crown. Nevertheless, the diminished trend of soil temperature in agroforestry could be owing to shade cast by the crown of the jackfruit trees. In open field, sunlight easily penetrate to the root system resulting increased soil temperature but sunlight cannot easily penetrate to the root system in agroforestry (Tanga et al., 2014; Mukherjee et al., 2008).

The higher economic return from jackfruit based agroforestry system might be due to several reasons for instance i) the presence of trees in crop fields has a positive effect on crop productivity, due to combinations of depositing mulch and nutrients, shade cover for exposed soils, reduced erosion, trapping airborne topsoil, and attracting animals and birds who deposit manure and urine, ii) surpluses resources of jackfruit tree e.g. firewood, construction timber and non-timber can be sold to diversify household income, iii) natural resources generated by jackfruit trees and restored habitats sustainably increase consumption by rural households and reduce expenditures on farm inputs such as fertilizers, fodder for livestock's and household needs. All of these factors augmented farm income compare to traditional land use systems. The outcomes what we found are corroborate by Hasan et al. (2008) in jackfruit-pineapple agroforestry production system, Hossain et al. (2015) at fruit-tomato based agroforestry systems. 


\section{Acknowledgements}

This study was funded by National Agriculture Technology Project (NATP) under Sponsored Public Goods Research (SPGR) of Bangladesh Agricultural Research Council (BARC). We thank to the project members of SPGR for their valuable suggestions during field study. We also thank all faculty members and staffs of Department of Agroforestry and Environment, Bangabandhu Sheikh Mujibur Rahman Agricultural University, Bangladesh.

\section{References}

Abdullah HM, Rahman MM. 2015. Initiating rainwater harvest technology for climate change induced drought resilient agriculture: Scopes and challenges in Bangladesh. Journal of Agriculture and Environment for International Development. 109: 189-208.

Arimond M, Hawkes C, Ruel MT, Sifri Z, Berti PR, Leroy JL. 2010. Agricultural interventions and nutrition: Lessons from the past and new evidence. In: Thompson B, Amoroso L, eds., Combating micronutrient deficiencies: Food-based approaches. Rome: Food and Agriculture Organization of the United Nations and CAB International, pp. 41-75.

BBS, 2011. Bangladesh Population and Housing Census 2011. Socio-Economic and Demographic Report. National Report Volume 4. Bangladesh: Statistics and Information Division, Ministry of Planning.

Bhardwaj BB, Gupta SR, Saini R, Sodhi JS, Singh A. 2005. Nutrient dynamics in a populusdeltoides agroforestry system at Kurukshetra. Bulletin of the National Institute of Ecology, 15: 99-108.

Donahue RL, Miller RW, Shickluna JC. 1987. Soils: An introduction to soils and plant growth. Prentice-Hall, New Delhi, India.

Anonymous, 2013. The Millennium Development Goals: Bangladesh Progress Report 2012. General Economics Division, Bangladesh Planning Commission. People`s Republic of Bangladesh, Dhaka, Bangladesh.

Hanif MA, Amin MHA, Bari MS, Ali MS, Uddin MN. 2010. Performance of okra under litchi based agroforestry system. Journal of agroforestry and environment. 4: 137-139.

Hasan M, Rahim MA, Islam AKMS, Rahman MM, Rahman MA, Naher N. 2016. Effect of management practices on the growth and yield of lime and lemon. International Journal of Bioscience. 8(6): 22-33.

Hasan MK, Ahmed MM, Miah MG. 2008. Agro Economic Performance of Jackfruit-Pineapple Agroforestry System in Madhupur Tract. Journal of Agriculture \& Rural Development. 6: $147-156$.

Hossain J, Ahmed T, Hasnat MZ, Karim D. 2015. Screening of tomato varieties for fruit tree based agroforestry system. International Journal of Agricultural Research, Innovation and Technology. 4: 61-69.

Islam MS, Sattar MA, Rahman MM, Qayum MA, Alam MS, Mustafi A. 2004. Krishi Projukti Hatboi (Handbook on Agrotechnology), 3rd Ed. Bangladesh Agricultural Research Institute, Gazipur- 1701, Bangladesh.

Islam AKMS, Rana MS, Rahman MM, Mian MJA, Rahman MM, Rahman MA, Naher N. 2016. Growth, yield and nutrient uptake capacity of rice under different sulphur levels. Turkish J Agri.Food Sci. Techno. 4(7): 557-565.

Lasco RD, Habito MS, Delfino RJP, Pulhin FB, Concepcion RG. 2011. Climate Change Adaptation Guidebook for Smallholder Farmers in Southeast Asia. Philippines: World Agroforestry Centre.
Lehmann J, Gebauer G, Zech W. 2002. Nitrogen cycling assessment in a hedgerow intercropping system using $15 \mathrm{~N}$ enrichment. Nutrient Cycling in Agroecosystems. 62: 1-9.

Mead R, Willey RW. 1980. The concept of "Land Equivalent Ratio" and advantages in yields from intercropping. Experimental Agriculture. 16: 217-228.

Miah MMU, Islam MS, Sikder MSI, Mondol MAS, Huda S. 2008. Performance of Tomato under Ghoraneem and Sissoo Based Agroferestry Systems. Journal of innovation and development strategy. 1: 39-42.

Miah MG, Ahmed FU, Ahmed MM, Alam MN, Choudhury NH, Hamid MA. 2002. Agroforestry in Bangladesh: Potential and opportunities. Paper presented in South Asia Regional Agroforestry Consultation Workshop held on 23-25 November, 2002 at New Delhi. India

Morandi, B., Zibordi, M., Losciale, P., Manfrini, L., Pierpaoli, E., \& Grappadelli, L. C. (2011). Shading decreases the growth rate of young apple fruit by reducing their phloem import. Scientia Horticulturae, 127, 347-352.

Mukherjee A, Banerjee S, Nanda MK, Sarkar S. 2008. Microclimate study under agroforestry system and its impact on performance of tea. Journal of Agrometeorology. 10: 99-105.

Nair P, Kumar B, Nair V. 2009. Agroforestry as a strategy for carbon sequestration. Journal of Plant Nutrition and Soil Science. 172: 10-23.

Rahman KM, Mondol MA, Rahman GMM, Harun-or-Rashid M, Shamsunnahar M. 2010. Performance of tomato under multistoried agroforestry system. Journal of agroforestry and environment. 4: 109-111.

Rahman MM, Haque MA, Nihad SAI, Akand MMH, Howlader MRA. 2016. Morpho-physiological response of Acacia auriculiformis as influenced by seawater induced salinity stress. Forest Systems. 25: e071. doi.org/10.5424/fs/2016253-09386

Rahman MM, Rahman MA, Miah MG, Saha SR, Karim MA and Mostofa MG. 2017. Mechanistic insight into salt tolerance of Acacia auriculiformis: the importance of ion selectivity, osmoprotection, tissue tolerance and $\mathrm{Na}+$ exclusion. Frontiers in Plant Science. 8, 155. doi:10.3389/fpls.2017.00155

Rich M, Lesley O, Kavita S, Golam K, Setara R. 2015. USAID Office of Food for Peace Food Security Country Framework for Bangladesh (FY 2015-2019). Washington, DC: FHI 360/FANTA.

Sarvade S, Mishra HS, Kaushal R, Chaturvedi S, Tewari S, Jadhav TA. 2014. Performance of wheat (Triticum aestivum L.) crop under different spacing of trees and fertility levels. African Journal of Agricultural Research. 9: 866-873.

Schoeneberger M, Bentrup G, Gooijer H, Soolanayakanahally R, Sauer T. 2012. Branching out: Agroforestry as a climate change mitigation and adaptation tool for Agriculture. Journal of Soil and Water Conservation, 67, 128-36.

Tanga AA, Erenso TE, Lemma B. 2014. Effects of three tree species on microclimate and soil amelioration in the central rift valley of Ethiopia. Journal of Soil Science and Environmental Management. 5: 62-71.

Uddin MN, Miah MMU, Rahman MS, Amin MHA, Rahman MS. 2010. Performance of Indian spinach in litchi based Agroforestry system. Journal of agroforestry and environment. 4: 97-100.

Weaver JE, Clements FE. 1973. In Plant Ecology. Tata McGrawHill Publishing Co., New Delhi, 2nd Ed.

Yamaguchi M, Haji T, Yaegaki H. 2004. Differences in mesocarp cell number, cell length, and occurrence of gumming in fruit of Japanese apricot (Prunus mume Sieb. Zucc.) cultivars during their development. Journal of the Japanese Society for Horticultural Science. 73: 200-207.

Zhang C, Tanabe K, Wang S, Tamura F, Yoshida A, Matsumoto K. 2006. The impact of cell division and cell enlargement on the evolution of fruit size in Pyrus pyrifolia. Annals of Botany, 98: 537-543. 